\title{
Peran Partai Golkar Dalam Melaksanakan Pendidikan Politik Bagi Masyarakat Kabupaten Bone Menurut Undang-Undang Nomor 2 Tahun 2011 Tentang Partai Politik (Studi Dewan Pimpinan Daerah Partai Golkar Kabupaten Bone
}

\author{
Muhammad Ihsan \\ Institut Agama Islam Negeri (IAIN BONE) \\ muhammadihsaniainbone@gmail.com
}

\begin{abstract}
Abstrak
Penelitian ini bertujuan untuk mendiskripsikan Peran Dewan Pimpinan Daerah Partai Golkar Kabupaten Bone dalam melaksanakan pendidikan politik. Jenis penelitian ini adalah jenis penelitian lapangan (field research). Teknik pengumpulan data dengan menggunakan metode observasi, wawancara, dan dokumentasi. Untuk menguji keabsahan data dalam penelitian ini yaitu menggunakan sumber data, dan metode atau teknik pengumpulan data. Hasil dalam penelitian ini bahwa Peran Dewan Pimpinan Daerah Partai Golkar Kabupaten Bone dalam memberikan pendidikan politik di kabupaten Bone menunjukan peran yang sangat penting dalam melakukan pendidikan politik. Untuk menarik simpati dari masyarakat Dewan Pimpinan Daerah Partai Golkar Kabupaten Bone melakukan kegiatan pendidikan politik dengan terjun langsung ke masyarakat melalui forum pertemuan warga dengan menyampaikan program partai dan visi misi partai juga menanamkan rasa nasionalisme, kebangsaan, kebinekaan, dan demokrasi begitu juga memberikan arahan cara berpolitik yang baik dan benar. Tujuan partai Golkar yang utama adalah ingin mencerdaskan kehidupan bangsa Indonesia dan mensejahterakan masyarakat. Partisipasi partai Golkar dalam pendidikan politik Dewan Pimpinan Daerah Partai Golkar Kabupaten Bone mengadakan diklat karater kepada kader partai agar mampu memberikan penjelasan tentang politik ke masyarakat.Pencapaian yang diinginkan partai Golkar adalah menciptakan masyarakat adil dan makmur, mewujudkan kedaulatan rakyat dalam rangka mengembangkan kehidupan demokrasi, menghormati dan menjunjung tinggi kebenaran, keadilan, hukum dan HAM. Adapun penyebab-penyebab rendahnya tingkat pertisipasi politik masyarakat di kabupaten Bone disebabkan oleh kurangnya kesadaran masyarakat, pertimbangan ekonomi, merasa apatis dan pesimis terhadap politik disebabkan para politisi menghalangkan segala cara untuk mendapatkan kursi kekuasaan misalnya memanipulasi dan berbohong/menipu rakyat.
\end{abstract}


Kata Kunci : Partai Golkar, Pendidikan Politik Bagi Masyarakat, dan UndangUndang Nomor 2 Tahun 2011 Tentang Partai Politik

\section{Pendahuluan}

Partai politik di Indonesia telah melewati tiga tahapan dalam perkembangan kehidupan kepartaian di Indonesia terhitung dari partai politik di era orde lama, partai politik di era orde baru, dan partai politik di era reformasi. ${ }^{62}$ Sedangkan undangundang yang mengatur tentang partai politik Indonesia telah mengalami perubahan, sebanyak 9 kali. Adapun undang-undang yang mengatur tentang partai politik diantaranya: Maklumat X Wakil Presiden Muhammad Hatta Tahun 1945, penetapan Presiden RI Nomor 7 Tahun 1959 tentang Sjarat-Sjarat dan Penjederhanaan Kepartaian, Peraturan Presiden Nomor 13 Tahun 1960 tentang Pengakuan, Pengawasan dan Pembubaran Partai Politik, Undang-undang Nomor 3 Tahun 1975 tentang Partai Politik dan Golongan Karya, Undang-undang Nomor 3 Tahun 1985 tentang Perubahan atas Undang-undang Nomor 3 Tahun 1975 tentang Partai Politik dan Golongan Karya, Undang-undang Nomor 2 Tahun 1999 tentang Partai Politik, Undang-undang Nomor 31 Tahun 2002 tentang Partai Politik, Undang-undang Nomor 2 Tahun 2008 tentang Partai Politik, dan Undang-undang Nomor 2 Tahun 2011 tentang Perubahan atas Undang-undang Nomor 2 Tahun 2008 tentang Partai Politik. $^{63}$

Politik secara bahasa dalam bahasa Arab disebut as-siyasah yang berarti mengelola, mengatur, memerintah dan melarang sesuatu. Atau secara definisi berarti prinsip-prinsip dan seni mengelola persoalan publik. ${ }^{64}$ Ketika seseorang mengatakan: sustu arraiyah, berarti ia memerintah sekelompok masyarakat atau melarangnya. Selain itu, kata siyasah, juga diartikan sebagai satu bentuk aktivitas yang mengacu perbaikan. Dengan demikian, dapat disimpulkan bahwa siyasah secara terminologi

${ }^{62}$ Abdul Mukthie Fadjar, Partai Politik Dalam Perkembangan Ketatanegaraan Indonesia, Edisi Revisi, (t.c. ; Malang: Setara Press, 2012), h. 3.

${ }^{63}$ Wikipedia. dikutip pada laman website, https://id.wikipedia.org/wiki/partai-politik-di Indonesia, diakses pada hari Minggu 23 September 2017, Pukul 11:24 Wita.

${ }^{64}$ Muhammad Elvandi, Inilah Politikku, ([t.Ed]), (t.c. ;Solo; PT. Era Adicitra Intermedia, 2011), h. 43 . 
adalah satu bentuk interaksi yang dilakukan oleh seseorang dengan tujuan untuk mengatur stabilitas sosial politik ke arah yang lebih baik. ${ }^{65}$

Dalam perspektif ulama fikhi memandang politik sebagai salah satu bentuk interaksi yang dilakukan oleh seorang pemimpin secara evolusioner untuk mencapai satu maslahah sekalipun tidak dapat diperkuat oleh sebuah teks atau dalil agama. Dapat pula diartikan sebagai bentuk pengaturan yang dilakukan oleh pemerintah ditengah-tengah komunitas masyarakat plural, baik yang terkait dengan masalah keagamaan maupun terkait dengan masalah kehidupan dunia semata demi terciptanya suasana yang lebih baik.

Dari penjelasan tersebut dapat dipahami pandangan Islam terhadap politik dapat dimaknai sebagai sistem hukum yang diberlakukan untuk mengatur stabilitas negara serta membangun kesejahteraan rakyat dengan satu konsekuensi bahwa setiap kebijakan mesti dilakukan secara paradigmatik sehingga tidak kontroversi dengan nilai moralitas agama. Untuk itu ulama Islam telah melakukan klasifikasi dari suatu aktivitas politik ke dalam beberapa variabel. Pertama, perilaku politik yang mengarah pada perbaikan secara menyeluruh dalam sebuah komunitas masyarakat dengan tujuan menciptakan kesetaraan dalam semua aspek kehidupan sehingga pada akhirnya mereka lebih merasakan ketenangan dan kenyamanan dalam setiap interaksi yang dilakukannya. Sistem politik semacam ini dijuridis sebagai implementasi dari nilainilai moralitas serta prinsip-prinsip sakral. Perilaku politik seperti inilah yang kemudian disebut dengan siyasih syar'iah dalam literature Islam.

Kedua, adalah satu bentuk perilaku politik yang mengarah pada kepentingan pribadi semata dan tidak menghiraukan kepentingan masyarakat, sehingga persoalanpersoalan yang mencuat ditengah-tengah mereka tidak mendapat perhatian serius. Maka dari itu perilaku politik semacam ini dianggap sebagai bagian dari pelaku yang mengarah pada ketidakadilan dan hanya untuk meligitimasi kekuasaan sehingga dalam konteks Islam dikategorikan sebagai siyaasah zalimah karena tidak menciptakan kenyamanan dalam memerintah. ${ }^{66}$

Dalam pandangan Islam, setiap aktivitas politik hendaknya terbangun atas dasar moral dan nilai esensi agama seperti kejujuran, keadilan, amanah dan sebagainya. Namun demikian tidak berarti bahwa setiap kebijakan politik yang kemudian dapat dilegitimasi sebagai tindakan yang bijak harus terimplementasi dari

${ }^{65}$ Lukman Arake, Islam dan Konseptualisasi Politik Kaum Minoritas, ([t.Ed]), (Cet.1; Yogyakarta: Prudent Media, 2012), h. 3.

${ }^{66}$ Lukman Arake, Islam dan Konseptualisasi Politik Kaum Minoritas, h. 4. Jurnal Al-Dustur; VOLUME 1 NO 1, DESEMBER 2018 
setiap masalah yang telah dijelaskan secara detail dan transparan oleh teks-teks agama, karena setiap perilaku politik dapat saja dianggap sebagai tindakan yang benar selama hal tersebut sejalan dengan nilai-nilai moralitas agama itu sendiri. Itulah sebabnya Ibnu Akil seorang tokoh ulama klasik pernah menolak pernyataan Imam Syafi'i bahwa : "Suatu kebijakan tidak dapat dianggap sebagai kebijakan politik bila tidak sesuai dengan apa yang telah dijelaskan oleh agama secara detail dan transparan". Beliau menegaskan bahwa jika yang dimaksud dari pernyataan tersebut adalah bahwa setiap kebijakan politik dianggap sebagai tindakan yang tidak benar bila kontradiksi dengan nilai-nilai moralitas agama, maka pernyataan itu benar. Sebaliknya bila yang dimaksud dari pernyataan tersebut adalah bahwa setiap kebijakan politik tidak akan dianggap benar bila tidak sesuai dengan apa yang telah diuraikan oleh agama secara detail, terperinci dan transparan, maka pernyataan itu kurang tepat, karena tidak sesuai dengan fakta-fakta sejarah dimana sebahagian besar sahabat Nabi telah melakukan kebijakan publik padahal tidak dijelaskan hukumnya secara terperinci dan transparan di dalam agama. ${ }^{67}$

Sebagai contoh, proses penyatuan ayat-ayat Al-Qur'an dalam satu mushaf seperti yang dilakukan Abu Bakar. Ini menandakan bahwa setiap perilaku politik tetap dinilai sebagai hal yang aflikatif selama tidak melanggar nilai-nilai yang ada dalam agama. Dengan demikian pembahasan tersebut cukup signifikan untuk menyadari bahwa politik didalam Islam menempati urgen dan tidak sempit. ${ }^{68}$

Politik dalam pandangan Islam dalam hal ini Abdurrahman Ibnu Khaldun dengan sederhana memberikan naratif bahwa perilaku politik seseorang tidak terlepas dari nilai-nilai etika dalam berpolitik diantaranya adalah :

a) Almalik Attabii yaitu perilaku politik seseorang pemimpin yang hanya berdasarkan intuisi semata. Jadi, semua bentuk perilaku yang dilakukan seseorang politisi dalam mencapai satu tujuan tidak terlepas dari pengaruh intuisi yang dimiliki, sehingga besar kemungkinan sangat otoriter dalam pengambilan sebuah keputusan. Oleh karena itu, Ibnu Khaldun memandang bagian ini sebagai perilaku yang tidak terpuji. ${ }^{69}$

\footnotetext{
${ }^{67}$ Lukman Arake, Islam dan Konseptualisasi Politik Kaum Minoritas, h. 5.

${ }^{68}$ Lukman Arake, Islam dan Konseptualisasi Politik Kaum Minoritas, h. 6.

${ }^{69}$ Lukman Arake, Islam dan Konseptualisasi Politik Kaum Minoritas, h. 7.
} 
b) Almalik Assiyasi yaitu perilaku politik seorang pemimpin yang banyak dipengaruhi oleh akal dalam pengambilan sebuah keputusan sangat bergantung pada nilai rasionalisasi masalah. Bila perilaku tersebut dinilai rasional oleh publik maka akan signitifikan dan dapat diterima. Sebaliknya jika tidak dinilai sebagai hal yang rasional akan dianggap deskruktif dan tidak dapat diterima. Namun dalam prakteknya, para ahli hukum tetap menilai bahwa perilaku politik semacam ini setidaknya tidak dapat memberi dampak positif pada setiap individu sebagai bagian dari komunitas masyarakat yang ada misalnya rasa keadilan, kedamaian dan ketenteraman hidup. Hanya saja, corak politik seperti ini masih dianggap tabu dan kurang produktif, karena hanya mementingkan sisi duniawi saja dan kurang memperhatikan nilai-nilai spiritual agama. ${ }^{70}$

c) Perilaku politik seorang pemimpin yang tidak terlepas dari nilai moralitas agama. Segala aktivitas politik yang dilakukan seorang politisi, baik berupa terobosan baru atau upaya menarik empati masyarakat terkontaminasi oleh nilai yang ada sehingga kecil kemungkinan terjadi kecurangan. Selain itu keseimbangan antara privasi yang diberikan kepada setiap individu untuk menyatakan aspirasi politiknya akan tetap sejalan dengan petunjuk agama. ${ }^{71}$

Dari tiga poin diatas, Ibnu Khaldun menegaskan bahwa perilaku seorang politisi hendaknya masuk dalam nominasi yang ketiga, karena menurutnya bentuk tersebut menuntut keseimbangan antara integritas politik dengan nilai normatif agama. Maka setiap politisi yang mampu mengakselerasikan kedua poin tersebut akan dianggap berhasil. Sebaliknya bila tidak mampu maka gebrakan-gebrakan politiknya akan dianggap sebagai jargon belaka, bahkan tidak menutup kemungkinan mengalami impase. ${ }^{72}$

Bagi umat Islam, mengangkat pemimpin merupakan kewajiban yang harus dilaksanakan. Keberadaannya memiliki peran yang cukup fundamental dalam kehidupan umat. Syariat Islam tidak akan tegak secara kaffah kecuali di bawah perlindungan sebuah kepemimpinan. Karena dalam Islam, kita tidak hanya diperintahkan shalat, puasa, sedekah dan sebagainya yang bisa dilakukan secara individual.

\footnotetext{
${ }^{70}$ Lukman Arake, Islam dan Konseptualisasi Politik Kaum Minoritas, h. 8.

${ }^{71}$ Lukman Arake, Islam dan Konseptualisasi Politik Kaum Minoritas, h. 10.

72 Lukman Arake, Islam dan Konseptualisasi Politik Kaum Minoritas, h. 12. Jurnal Al-Dustur; VOLUME 1 NO 1, DESEMBER 2018
} 
Tentunya sebagai muslim sejati, semua pilihan itu akan kita ukur sesuai dengan petunjuk Al-Qur'an dan Sunnah yang telah diajarkan oleh Rasulullah SAW dalam hadistnya sebagai berikut :

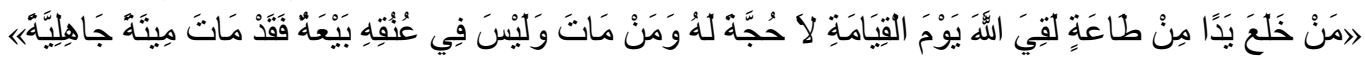

Terjemahannya:Siapa saja yang melepaskan ketaatan, maka ia akan bertemu Allah

pada hari kiamat tanpa memiliki hujjah. Dan siapa saja yang meninggal sedang di pundaknya tidak ada baiat, maka ia mati seperti mati jahiliyah (dalam keadaan berdosa). (HR. Muslim). ${ }^{73}$

Namun, seringkali setiap akan menghadapi pemilu, masyarakat kita sering dibuat bingung dalam menentukan siapa pemimpin yang layak mereka pilih. Sehingga, tidak sedikit di antara mereka yang memilih untuk golput. Banyak alasan yang terungkap, salah satunya selain kredibilitas dan kualitas calon pemimpin yang meragukan, masyarakat juga banyak dikecewakan dengan janji-janji palsu bakal calon pemimpin pada saat kampanye.

Didalam Undang-undang Dasar Tahun 1945 pada Bab XIII tentang Pendidikan dan Kebudayaan Pasal 31 ayat (1) yang berbunyi: "setiap warga negara berhak mendapat pendidikan." "74 Dari bunyi pasal 31 ayat (1) Undang-undang Dasar Tahun 1945 pada Bab XIII tentang Pendidikan dan Kebudayaan menegaskan bahwa warga negara Indonesia selain mendapatkan pendidikan dasar warga negara Indonesia berhak, untuk mendapatkan pendidikan politik.

Didalam Undang-undang Nomor 2 Tahun 2011 perubahan atas Undangundang Nomor 2 Tahun 2008 tentang Partai Politik. Salah satu fungsi partai politik di Indonesia adalah memberikan pendidikan politik bagi setiap warga negara hal ini sesuai dengan yang diamanatkan pada Bab XIII tentang Pendidikan Politik Pasal 31 ayat (1) yang berbunyi "partai politik melakukan pendidikan politik bagi masyarakat sesuai ruang lingkup tanggung jawabnya dengan memperhatikan keadilan dan kesetaraan gender." ${ }^{, 75}$ Dengan tujuan meningkatkan kesadaran hak dan kewajiban masyarakat dalam kehidupan bermasyarakat, berbangsa dan bernegara serta

${ }^{73}$ Ray. dikutip pada laman website, http://raystaycool.blogspot.co.id/2014/04/golput-dalamperspektif-islam_6.html, diakses pada hari Selasa 24 Oktober 2017, Pukul 17.33 Wita.

${ }^{74}$ Undang-Undang Dasar Tahun 1945, Bab XIII "Pendidikan dan Kebudayaan”, pasal 31 ayat(1).

${ }^{75}$ Undang-undang Nomor 2 Tahun 2011 perubahan atas Undang-undang Nomor 2 Tahun 2008 tentang Partai Politik, Bab XIII "Pendidikan Politik", Pasal 31 ayat (1). 
meningkatkan partisipasi politik dan inisiatif masyarakat dalam kehidupan bermasyarakat, berbangsa, dan bernegara.

Pada masa sekarang ini partisipasi warga negara dalam menyukseskan penyelenggaran pemilihan umun belum maksimal, keikutsertaan pemilih dan pemula masih rendah utamanya para pemula dan pemilih di Kabupaten Bone. Hal ini terlihat pada saat dilansanakan pemilihan presiden dan wakil di Indonesia pada tanggal 9 juli tahun 2014 banyak pemilih dan pemula di Kabupaten Bone yang golput. Seperti yang terjadi di Kecamatan Awangpone Kabupaten Bone. ${ }^{76}$

Dari data yang dihimpun oleh Bonepos, angka golput di Kecamatan Awangpone ini menembus angka sekitar 22 persen, dimana data tersebut berdasarkan sampel yang diperoleh dari 18 desa yang ada dikecamatan tersebut. Dari 16 desa yang terdaftar dalam DPT, DPTB DPK dan DPKTB mencapai 19.106 dan yang menyalurkan hak suaranya sebanyak 14.735. sehingga jika dikalkulasikan terdapat sekitar 4.300 lebih warga negara yang tidak menyalurkan hak pilih atau sekitar 22 persen.

Adapun angka golput yang tertinggi di 16 desa itu adalah Desa Carebbu, dimana angka golput di wilayah tersebut mencapai 33 persen dan yang paling rendah yaitu Desa Mappolo Ulaweng yakni sekitar 5 persen.

Menurut penulis, salah satu cara untuk menyelesaikan permasalahan diatas adalah partai politik seharusnya memberikan pendidikan politik kepada warga negara khususnya kepada para pemula dan pemilih di Kabupaten Bone untuk meningkatkan kesadaran akan hak dan kewajiban sebagai warga negara Indonesia. Berdasarkan semua penjelasan diatas mendorong penulis untuk menulis skripsi ini dengan judul

“Peran Partai Golkar Dalam Melaksanakan Pendidikan Politik Bagi Masyarakat Kabupaten Bone Menurut Undang-Undang Nomor 2 Tahun 2011 Tentang Partai Politik (Studi Dewan Pimpinan Daerah Partai Golkar Kabupaten Bone)"

\section{Rumusan Masalah}

Berawal dari latar belakang di atas, maka penulis mengambil kesimpulan rumusan masalah sebagai berikut:

76 Bonepos dikutip pada laman website http//wwwbonepos.com./2014/07/angka-golput-dikecamatan-awangpone.html. diakses pada senin 13 November 2017, Pukul 17:16 Wita.

Jurnal Al-Dustur; VOLUME 1 NO 1, DESEMBER 2018 
44 | Muhammad Ihsan

1. Bagaimana Bentuk Pendidikan Politik yang dilakukan oleh Dewan Pimpinan Daerah Partai Golkar Kabupaten Bone dalam melaksanakan pendidikan politik bagi masyarakat di kab.Bone?

2. Bagaimana kendala yang dihadapi oleh Dewan Pimpinan Daerah Partai Golkar Kabupaten Bone dalam melaksanakan pendidikan politik bagi masyarakat di kab.Bone ?

\section{Defenisi Operasional}

Untuk menghindari kesimpangsiuran dalam menafsir dan memahami maksud yang terkandung dalam judul skripsi ini, maka penulis merasa perlu menegaskan arti kata yang terdapat dalam judul ini.

Peran adalah tugas utama yang harus dilakukan. ${ }^{77}$

Partai politik adalah organisasi politik resmi yang dibentuk oleh orangorang yang mempunyai kepentingan yang sama dengan tujuan untuk menguasai pemenrintahan dengan cara menempatkan anggota-anggota mereka dalam pemenrintahan melalui mekanisme pemilihan umun. ${ }^{78}$

Pendidikan politik adalah proses pembelajaran dan pemahaman tentang hak, kewajiban, dan tanggung jawab setiap warga negara dalam kehidupan berbangsa dan bernegara melalui media berupa sekolah, pemenrintah dan juga partai politik. $^{79}$

\section{Tujuan dan Kegunaan}

Adapun tujuan penulis

1. Untuk mengetahui bagaimana bentuk pendidikan politik yang dilakukan oleh Dewan Pimpinan Daerah Partai Golkar Kabupaten Bone dalam melaksanakan pendidikan politik bagi masyarakat di kab.Bone.

77 Pusat Pembinaan dan Pengembangan Bahasa, Kamus Besar Bahasa Indonesia, Ed. 2, (Cet. 3;Jakarta: Balai Pustaka, 1994), h. 541.

78 Muhadam labola dan Teguh Ilham, Partai Politik Dan Sistem Pemilihan Umun Di Indonesia, h.15.

79 Muhadam labola dan Teguh Ilham, Partai Politik Dan Sistem Pemilihan Umun Di Indonesia, h.21. 
2. Untuk mengetahui bagaimana kendala yang dihadapi oleh Pimpinan Daerah Partai Golkar Kabupaten Bone dalam melaksanakan pendidikan politik bagi masyarakat di kab.Bone.

Kegunaan penelitian ini ada secara ilmiah dan praktis adalah sebagai berikut:

1. Kegunaan Ilmiah

Diharapkan hasil penelitian ini dapat memberi kontribusi terhadap perkembangan ilmu pengetahuan khususnya, di bidang Ilmu Hukum Tata Negara.

2. Kegunaan Praktis

a. Bagi pemerintah :

Diharapkan hasil penelitian ini dapat digunakan sebagai bahan masukkan untuk meningkatkan pemahamaan mengenai bentuk pendidikan politik yang dilakukan oleh Dewan Pimpinan Daerah Partai Golkar Kabupaten Bone dalam melaksanakan pendidikan politik bagi masyarakat di kab.Bone.

b. Bagi masyarakat :

Memberikan Gambaran yang nyata bentuk pendidikan Politik yang dilakukan oleh Dewan Pimpinan Daerah Partai Golkar Kabupaten Bone dalam melaksanakan pendidikan politik bagi masyarakat di kab.Bone.

\section{Tinjauan Pustaka}

Hasil yang penulis pahami baik berupa karya tulis, skripsi, jurnal ataupun yang lain, telah banyak karya-karya yang ditemukan yang membahas persoalan pendidikan politik. Namun dalam mencari referensi tentang Peran Partai Golkar Dalam Melaksanakan Pendidikan Politik Bagi Masyarakat Kabupaten Bone Menurut Undang-Undang Nomor 2 Tahun 2011 Tentang Partai Politik, ada karya-karya yang dapat disebutkan disini yang menjadi acuan penulis dalam mengemukakan materi yang akan diteliti, karya-karya tersebut sebagai berikut :

Dalam skripsi yang disusun oleh Saudara Andi Ardian Syahruddin Mahasiswa Universitas Hasanuddin Makassar Program Studi Ilmu Hukum tahun 2016 yang berjudul “Tinjauan Yuridis Pelaksanaan Pendidikan Politik Bagi Masyarakat oleh Partai Politik di kota Makassar Berdasarkan Undang-undang Nomor 2 Tahun 2011 tentang Partai Politik". Skripsi ini membahas mengenai pelaksanaan pendidikan politik bagi masyarakat oleh partai politik di kota Makassar. Menurut Andi Adrian Syahruddin pelaksanaan pendidikan politik yang dilakukan oleh partai politik di kota Makassar terlebih dahulu merumuskan program terkait dengan pendidikan politik, yang mengacu pada AD/ART partai. Sedangkan bentuk pendidikan politik bagi 
masyarakat oleh partai politik di kota Makassar dalam bentuk seminar dan sosialisasi hal ini sesuai dengan peraturan perundangan yang berlaku. ${ }^{80}$

Dalam skripsi yang disusun oleh Saudari Wilis Putri Hapsari Mahasiswi Universitas Negeri Yogyakarta Program Studi Ilmu Pendidikan tahun 2017 yang berjudul "Pendidikan Politik di SD Masjid Syuhada Yogyakarta". Skripsi ini membahas mengenai pelaksanaan pendidikan di Sekolah Dasar Masjid Syuhada. Menurut Wilis Putri Hapsari pendidikan politik di SD Masjid Syuhada Yogyakarta menerapkan pendidikan politik melalui dua proses pembelajaran yaitu didalam kelas dan kegiatan diluar kelas. Pelaksanaan pendidikan politik didalam kelas melalui kurikulum mata pelajaran tertentu yang memuat pendidikan politik. Sedangkan pendidikan politik yang dilakukan diluar kelas melalui kegiatan pengembangan diri untuk melatih sikap politis siswa diantaranya, kegiatan ekstrakurikuler yang bersifat wajib bagi siswa-siswi seperti kegiatan pramuka dan patroli keamanan sekolah. ${ }^{81}$

Berdasarkan dari kedua bentuk penelitian di atas, penulis dapat menarik sebuah kesimpulan yaitu meskipun dari kedua penelitian tersebut dengan penelitian yang akan dilakukan oleh penulis memiliki kesamaan yaitu berfokus pada pendidikan politik. Namun sedikit berbeda dengan yang akan dikajian oleh penulis. Letak perbedaannya yaitu penulis mengkaji peran Dewan Pimpinan Daerah Partai Golkar Kabupaten Bone dalam memberikan pendidikan politik bagi masyarakat Kab.Bone melalui penelitian secara lapangan yang akan lebih terperinci secara utuh berdasarkan fakta yang ada.

\section{Kerangka Pikir}

Berdasarkan uraian yang telah dikemukakan sebelumnya, maka pada bagian ini diuraikan kerangka berpikir yang dijadikan sebagai landasan berpikir dalam melaksanakan penelitian. Pada dasarnya kerangka berpikir akan menjelaskan secara teoritis hubungan antar variable yang akan diteliti.

${ }^{80}$ Andi Adrian Syahruddin, "Tinjauan Yuridis Pelaksanaan Pendidikan Politik Bagi Masyarakat oleh Partai Politik di kota Makassar Berdasarkan Undang-undang Nomor 2 Tahun 2011 tentang Partai Politik." (Skripsi, Fakultas Hukum Universitas Hasanuddin, Makassar, 2016), h. iii.

${ }^{81}$ Wilis Putri Hapsari, "Pendidikan Politik di SD Masjid Syuhada Yogyakarta", (Skripsi, Fakultas Ilmu Pendidikan Universitas Yogyakarta, 2017), h. iii. 
Adapun kerangka pikir yang dimaksud adalah sebagai berikut:

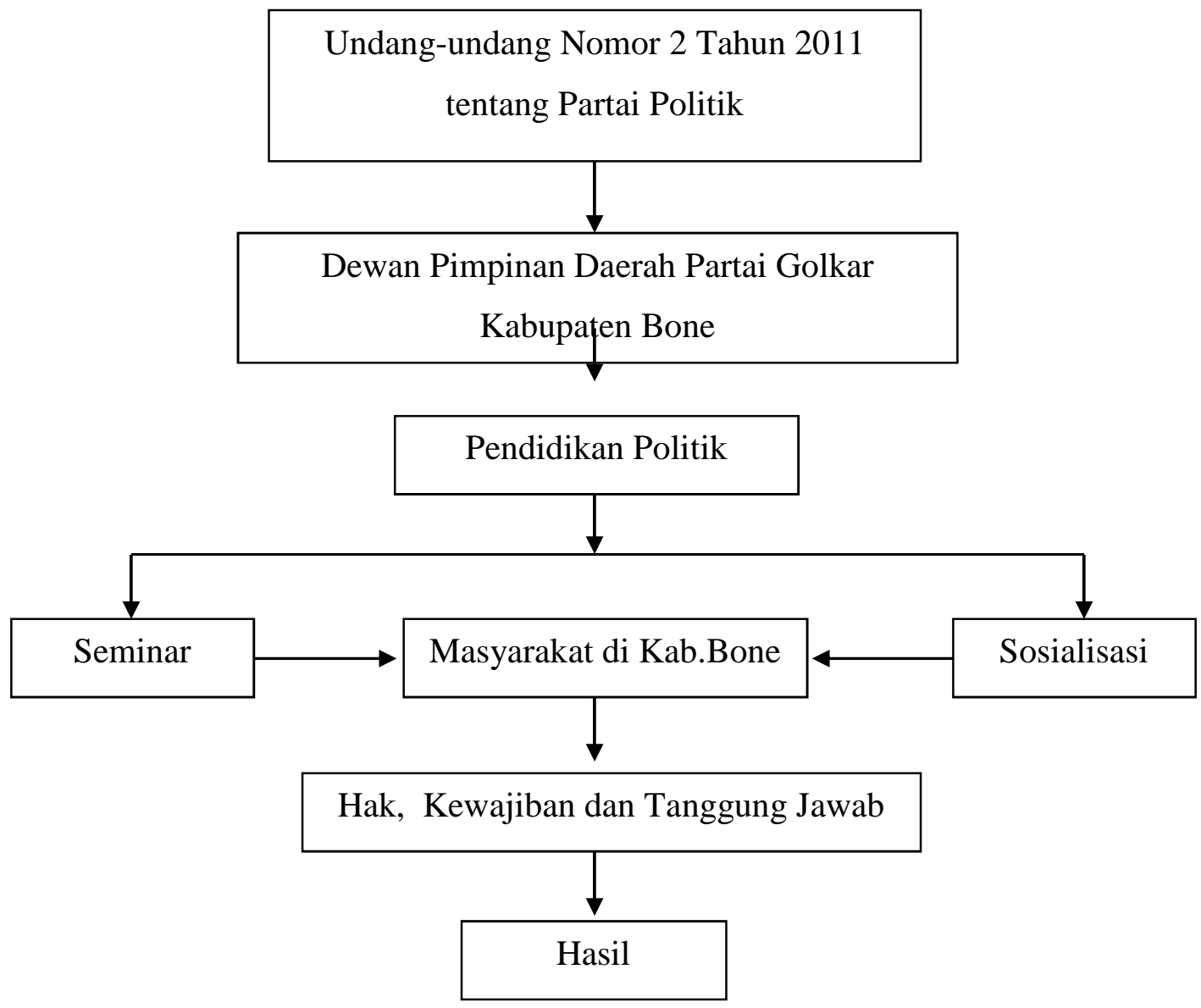

Dalam bagan di atas dapat dijelaskan bahwa Undang-undang Nomor 2 Tahun 2011 merupakan undang-undang yang mengatur tentang partai politik di Indonesia. Undang-undang Nomor 2 Tahun 2011 tentang Partai Politik mulai berlaku pada tanggal 15 Januari tahun 2011.

Dewan Pimpinan Daerah Partai Golkar Kabupaten Bone dapat memberikan materi pendidikan politik melalui kegiatan seminar dan sosialisasi kepada masyarakat di Kab.Bone. untuk mengingatkan hak, kewajiban dan tanggung jawabnya dalam kehidupan berbangsa dan bernegara. 


\section{Metode Penelitian}

3. Jenis dan Pendekatan Penelitian

Penelitian ini adalah jenis penelitian lapangan. Penelitian lapangan adalah penelitian yang langsung berhubungan dengan objek yang akan diteliti untuk memperoleh keterangan mengenai bentuk pendidikan politik yang dilakukan oleh Dewan Pimpinan Daerah Partai Golkar Kabupaten Bone dalam memberikan pendidikan politik bagi masyarakat Kab.Bone. Berdasarkan permasalahan yang akan dikemukakan, maka penelitian ini menggunakan pendekatan penelitian yaitu pendekatan normatif-empiris. Adapun penjelasannya lebih jelas yaitu sebagai berikut:

a. Pendekatan yuridis normatif adalah jenis pendekatan yang mengacu pada norma

hukum yang terdapat dalam peraturan perundang-undangan dan putusan pengadilan serta norma-norma yang hidup dan berlaku di masyarakat. ${ }^{82}$

b. Pendekatan yuridis empiris adalah jenis pendekatan yang dilakukan dengan pendekatan pada realitas hukum dalam masyarakat. ${ }^{83}$

Alasannya, penelitian ini menggunakan pendekatan normatif-empiris yaitu agar dapat mengetahui suatu aturan hukum dan kemudian melihat realitasnya di masyarakat.

4. Lokasi Penelitian

Penelitian ini berlokasi di Kantor Dewan Pimpinan Daerah Partai Golkar Kabupaten Bone yang beralamat di Jalan Besse Kajuara Kecamatan Tanete Riattang Barat. Alasannya memilih lokasi ini yaitu sebagai salah satu partai politik yang berperan penting dalam memberikan pendidikan politik bagi warga negara dan juga sebagai salah satu partai politik yang berperan penting menyukseskan penyelenggaraan pemilihan umum.

5. Data dan Sumber Data

Menurut Kamus Besar Bahasa Indonesia, data berarti keterangan yang benar dan nyata, atau bahan nyata yang dapat dijadikan sebagai dasar kajian (analisis atau kesimpulan). Data merupakan keterangan-keterangan tentang suatu fakta. Menurut Prastowo, data dalam bahasa latin date berarti member. ${ }^{84}$ Dalam penelitian ini data yang digunakan adalah data kualitatif. Data kualitatif adalah data yang tidak

\footnotetext{
${ }^{82}$ Syahruddin Nawawi, Penelitian Hukum Normatif Versus Penelitian Hukum Normatif, ([t.Ed]), (Cet. 2; Makassar: PT Umitoha Ukhuwwah Grafika, 2014), h. 7.

${ }^{83}$ Syahruddin Nawawi, Penelitian Hukum Normatif Versus Penelitian Hukum Normatif, h. 8.

${ }^{84}$ Andi Prasrowo, Memahami Metode Penelitian Suatu Tinjauan Teoritis dan Praktis, ([t.Ed]), (Cet. 2; Jogjakarta: Ar.Ruzz Media, 2013), h. 30.

Jurnal Al-Dustur; VOLUME 1 NO 1, DESEMBER 2018
} 
berbentuk angka yang diperoleh dari rekaman, pengamatan, wawancara, atau bahan tertulis. $^{85}$ Sedangkan sumber data dalam penelitian adalah subjek dari mana data diperoleh. ${ }^{86}$ Adapun yang menjadi sumber data dalam penelitian ini adalah berikut:

a. Data primer

Data primer merupakan data yang diperoleh langsung dari sumber pertama. ${ }^{87}$ Data primer adalah data yang langsung diperoleh berkaitan dengan objek penelitian, tidak soal mendukung dan melemahkannya. ${ }^{88}$ Data yang dimaksud adalah data yang berkenaan dengan bentuk pendidikan politik yang dilakukan oleh Dewan Pimpinan Daerah Partai Golkar Kabupaten Bone dalam memberikan pendidikan politik bagi masyarakat Kab.Bone. Data yang diperoleh langsung dari Kantor Dewan Pimpinan Daerah Partai Golkar Kabupaten Bone, yang beralamat di Jalan Besse Kajuara Kecamatan Tanete Riattang Barat.

b. Data Sekunder

Data sekunder mencakup dokumen-dokumen resmi, buku-buku, hasil penelitian yang berwujud laporan. ${ }^{89}$ Dalam penelitian ini akan menggunakan data sekunder sebagai berikut:

1) Undang-undang Nomor 2 Tahun 2011 tentang perubahan atas Undang-undang Nomor 2 Tahun 2008 tentang Partai Politik.

2) Buku-buku tentang pendidikan politik.

3) Skripsi, jurnal, dan makalah yang berkaitan dengan pendidikan politik bagi masyarakat.

6. Instrumen Penelitian

Instrumen penelitian merupakan alat yang digunakan dalam pengumpulan data. Dalam penelitian ini akan menggunakan alat yaitu daftar pertanyaan, recorder dari handphone dibantu alat tulis lainnya, kemudian dibuatkan transkripnya dengan

${ }^{85}$ M.Djunaidi Ghony dan Fauzan Alamanshur, Metodologi Penelitian Kualitatif, ([t.Ed]), (Cet.3; jogjakarta: Ar Ruzz Media, 2016), h.246.

${ }^{86}$ Suharsimi Arikunto, Prosedur Penelitian Suatu Pendekatan Praktek, ([t.Ed]), (Cet. XII; Jakarta: PT Rineka Cipta, 2002), h. 107.

${ }^{87}$ Amiruddin dan Zainal Asikin, Pengantar Metode Penelitian Hukum, ([t.Ed]), (Cet.1; Jakarta: PT. Grafindo Persada, 2004), h. 30.

${ }^{88}$ Andi Prasrowo, Memahami Metode Penelitian Suatu Tinjauan Teoritis dan Praktis, h. 31.

${ }^{89}$ Amiruddin dan Zainal Asikin, Pengantar Metode Penelitian Hukum, h. 30. Jurnal Al-Dustur; VOLUME 1 NO 1, DESEMBER 2018 
mengubah hasil wawancara tersebut dari bentuk rekaman menjadi bentuk tertulis. ${ }^{90}$ Selain itu, dalam penelitian ini juga menggunakan metode pengumpulan data berupa observasi dengan menggunakan instrumen penelitian berupa ceklist, kamera dan lainlain.

7. Teknik Pengumpulan Data

Teknik yang digunakan untuk mengumpulkan data dalam penelitian ini adalah:

a. Wawancara adalah percakapan dengan maksud tertentu. Percakapan itu dilakukan oleh dua pihak, yaitu pewawancara (interview) yang mengajukan pertanyaan dan terwawancara (interviewer) yang memberikan jawaban atas pertanyaan. ${ }^{91}$ Wawancara yang dilakukan bertujuan untuk mendapatkan keterangan atau penjelasan langsung dan narasumber terkait dengan objek penelitian.

Wawancara yang dilakukan dalam penelitian ini dapat diuraikan sebagai berikut:

1) Wawancara terstruktur atau biasa disebut teknik wawancara mendalam. Wawancara ini dimana peneliti menggunakan pedoman wawancara yang telah tersusun secara sistimatis dan lengkap untuk pengumpulan data. Dalam penelitian ini yang akan di wawancarai adalah Sekretaris DPD Partai Golkar Kab.Bone,Kepala Sekretariat DPD Partai Golkar Kab.Bone,Kader DPD Partai Golkar Kab.Bone dan masyarakat Kab.Bone.

2) Wawancara bebas atau wawancara tidak terstruktur. Wawancara ini dilakukan dimana peneliti tidak menggunakan pedoman wawancara yang telah tersusun secara sistematis dan lengkap untuk pengumpulan datanya. ${ }^{92}$

b. Observasi adalah teknik pengumpulan data dengan melakukan penelitian terhadap objek yang akan diteliti baik secara langsung maupun tidak langsung. Ada beberapa informasi yang akan diperoleh dari hasil observasi antara lain: ruang (tempat), pelaku, kegiatan, objek, perbuatan, kejadian, waktu, dan lain-lain.

\footnotetext{
${ }^{90}$ Muhammad Teguh, Metodologi Penelitian Ekonomi Teori dan Aplikasi, Ed. 1-3, (Cet.3 ;Jakarta: PT. Raja Grafindo Persada, 2005), h. 136-137.

${ }^{91}$ Lexy J. Moleong, Metodologi Penelitian Kualitatif, Ed. Revisi, (Cet. 22; Bandung: PT Remaja Rosdakarya, 2004), h. 189.

${ }^{92}$ Sugiyono, Metode Penelitian Pendidikan Pendekatan Kuantitatif, Kualitatif dan R\&D ([t.Ed]), (Cet.22 ; Bandung:Alfabeta, 2015 ), h. 233.
} 
c. Dokumentasi adalah teknik pengumpulan data yang tersimpan dalam bentuk dokumentasi. Pengumpulan dokumentasi diperlukan karena sumber data tidak hanya mengenai tempat dan orang, tetapi juga arsip-arsip dan dokumen. Oleh karena itu penulis menggunakan metode yaitu mencari data mengenai hal-hal variable berupa tulisan, buku, artikel yang relevan dengan tema penulisan skripsi ini.

8. Teknik Analisis Data.

Teknik analisis data adalah proses mengorganisasikan dan mengurutkan data ke dalam pola, kategori, dan satuan uraian dasar sehingga dapat ditemukan tema dan dapat dirumuskan ke dalam bentuk hipotesis kerja. Dalam menganalisis data penulis menggunakan analisis kualitatif. Analisis Kualitatif adalah pengaturan data secara logis dan sistimatis, dan analisis data itu dilakukan sejak awal peneliti terjun ke lokasi penelitian hingga pada akhir penelitian (pengumpulan data). ${ }^{93}$ Adapun tahapan analisis kualitatif sebagai berikut:

a. Pengumpulan data lapangan yakni dengan mengumpulkan data yang ditemukan di lapangan merupakan data kasar.

b. Reduksi data adalah proses memilih atau menyederhanakan, mengabstraksikan dan mentransformasikan data kasar yang baru dari lapangan. ${ }^{94}$

c. Penyajian data merupakan sekumpulan informasi yang tersusun secara sistematis yang kemungkinan adanya penarikan kesimpulan. ${ }^{95}$

\section{Hasil Penelitian}

Berdasarkan hasil wawancara dengan H. Firman Batari, SH.MH selaku Sekretaris DPD Partai Golkar Kabupaten Bone di kantor Lembaga Hukum dan Konsultasi Hukum (Citra Keadilan) menjelaskan manfaat dari pendidikan politik yaitu pendidikan politik yang dilaksanakan oleh DPD Partai Golkar Kabupaten Bone bertujuan untuk mengubah pola pikir masyarakat Kabupaten Bone tentang politik, yang sebagian masyarakat Bone berpendapat bahwa politik tidak bagus karena tujuan politik adalah mempertahankan dan merebut kekuasaan. Padahal tujuan politik adalah

${ }^{93}$ M.Djunaidi Ghony dan Fauzan Alamanshur, Metodologi Penelitian Kualitatif, h.247.

${ }^{94}$ Muhammad tholchah Hasan, dkk. Metode Penelitian Kualitatif Tinjauan Teoritis dan Praktis, ([t.Ed]), (Cet. 3; Surabaya: Visiress Media, 2009), h. 183.

${ }^{95}$ Muhammad tholchah Hasan, dkk. Metode Penelitian Kualitatif, h. 182. 
untuk memperjuangkan keadilan, kesejahteraan dan kebijaksanaan bagi masyarakat dan juga sebagai usaha yang diterapkan oleh warga negara untuk mewujudkan kebaikan bersama. $^{96}$

Dalam kesempatan yang sama, H. Firman Batari, SH., MH menambahkan bahwa bentuk pendidikan politik yang dilakukan oleh Partai Golkar di Aula kantor DPD Partai Golkar Kabupaten Bone dapat digolongkan dalam dua bentuk pendidikan politik yaitu pendidikan politik secara teoritis dan pendidikan politik praktis atau simulasi. Secara teoritis dapat dilakukan setiap saat berupa pertemuan dengan seluruh pengurus juga selain itu terkadang bahkan setiap 6 bulan sekali dilakukan pendidikan politik yang melibatkan masyarakat umum dan dilaksanakan khusus untuk pemilih dan pemula. Selain itu partai Golkar terhadap kadernya lebih banyak menampilkan pembinaan pendidikan politik dalam bentuk praktisi, jadi seluruh gerakan politik sampai pada tingkat kecamatan dan tingkat desa terkadang diadakan simulasisimulasi berkaitan dengan kepentingan politik pada saat itu atau event politik yang dihadapi pada saat itu dan diistilahkan dengan bentuk pendidikan politik sebagai praktek atau simulasi. ${ }^{97}$ Dalam memberikan pendidikan politik oleh DPD Partai Golkar Kabupaten Bone, penulis mewawancarai H. Andi Zainuddin, SH.MH selaku kader DPD Partai Golkar menjelaskan materi yang diberikan oleh DPD Partai Golkar Kabupaten Bone dalam melaksanakan pendidikan politik yaitu berupa posisi, hak, kewajiban dan tanggung jawab setiap warga negara dalam kehidupan berbangsa dan bernegara dan juga memberikan pemahaman kepada masyarakat bahwa untuk membangun bangsa harus ada politik untuk mewujudkan keadilan, kesejahteraan dan keteraturan dalam membangun suatu negara. ${ }^{98}$

Kendala atau hambatan bagi partisipasi politik masyarakat disebabkan pula oleh belum dilembagakannya sistem pendidikan politik masyarakat di Kabupaten Bone. Hal ini terlihat dengan masih minimnya anggaran pemerintah daerah yang dialokasikan dalam Anggaran Pendapatan Belanja Daerah (APBD) untuk pembiayaan

${ }^{96}$ H. Firman Batari, Sekretaris DPD Partai Golkar di kantor Lembaga Hukum dan Konsultasi Hukum (Citra Keadilan), wawancara oleh penulis tanggal 18 Januari 2018.

${ }^{97}$ H. Firman Batari, Sekretaris DPD Partai Golkar di kantor Lembaga Hukum dan Konsultasi Hukum (Citra Keadilan), wawancara oleh penulis tanggal 18 Januari 2018.

${ }^{98}$ H. Andi Zainuddin, SH., Kader DPD Partai Golkar, wawancara oleh penulis tanggal 23 Januari 2018. 
pemberdayaan atau pendidikan politik masyarakat. Selama ini Anggaran Pendapatan Belanja Daerah (APBD) paling banyak terkuras membiayai kegiatan-kegiatan fisik, sementara kegiatan-kegiatan non fisik seperti pemberdayaan atau pendidikan politik bagi masyarakat sangat minim.

Dalam hal ini semua upaya untuk menghimbau secara politik masyarakat di Kabupaten Bone terdapat beberapa kesulitan dalam pelaksanaan pendidikan politik yaitu $:^{99}$

1. Amat sulit untuk menyadarkan rakyat akan kondisi diri sendiri yang diliputi banyak kesengsaraan dan kemiskinan, sebagai akibat terlalu lamanya hidup dalam iklim penindasan, penghisapan dan penjajahan, sehingga mereka menjadi terbiasa hidup dalam serba kekurangan dan ketertinggalan. Sulit untuk mendorong mereka kearah konsientisasi diri mengungkapkan segala problema yang tengah dihadapi.

2. Apatisme politik dan sinisme politik yang cenderung menjadi sikap putus asa itu mengakibatkan rakyat sulit untuk mempercayai usaha-usaha edukatif dan gerakan-gerakan politik yang dianggap palsu dan menina-bobokan rakyat belaka. Sulit pula untuk mengajak untuk berpikir lain dengan nalar jernih. Bahkan banyak diantara massa rakyat yang takut pada kemerdekaan.

3. Dengan latar belakang pendidikan yang rendah atau kurang, rakyat kebanyakan sulit memahami kompleksitas situasi sosial dan politik disekitar dirinya.

4. Para penguasa yang otoriter cenderung tidak menghendaki adanya pendidikan politik, karena mereka berkepentingan sekali dengan status quo dan pelestarian rezimnya. Partisipasi aktif dan pengawasan terhadap jalannya pemerintahan oleh rakyat itu tidak dikehendaki, sebab mengurangi kebebasan dan kekuasaan organorgan ketatanegaraan. ${ }^{100}$

Berdasarkan wawancara penulis dengan H. Andi Zainuddin, SH.MH selaku kader DPD Partai Golkar Kabupaten Bone menjelaskan kendala yang dihadapi oleh DPD Partai Golkar Kabupaten Bone dalam melaksanakan pendidikan politik, kendalanya yaitu dana atau anggaran yang diperoleh DPD Partai Golkar Kabupaten Bone yang bersumber dari Anggaran Pendapatan Belanja Negara (APBN) dan Anggaran Pendapatan Belanja Daerah (APBD) untuk melaksanakan pendidikan politik anggaran atau dananya harus bersumber dari APBN dan APBD yang

\footnotetext{
${ }^{99}$ Kartini Kartono, Pendidikan Politik Sebagai Bagian dari Pendidikan Orang Dewasa, ([t.Ed]), (Cet.3; Bandung: Mandar Maju, 2009), h.72.

${ }^{100}$ Kartini Kartono, Pendidikan Politik Sebagai Bagian dari Pendidikan Orang Dewasa, h.73. 
anggarannya atau dananya untuk diprioritaskan dan dialokasikan untuk partai politik untuk melaksanakan agenda politiknya, akan tetapi terkadang anggaran atau dananya terlambat diberikan. ${ }^{101}$

Dia menambahkan, hal ini tentu menjadi permasalahan jika tidak ada dana untuk membiayai terlaksananya agenda partai politik yaitu memberikan pendidikan politik kepada masyarakat. Jika dana atau anggaran dari Anggaran Pendapatan Belanja Negara (APBN) dan Anggaran Pendapatan Belanja Daerah (APBD) terlambat diberikan kepada partai politik yang ingin melaksanakan pendidikan politik kepada masyarakat maka partai politik yang bersangkutan tersebut tidak dapat memberikan pendidikan politik kepada masyarakat, disebabkan untuk melaksanakan pendidikan politik anggaran atau dananya harus bersumber dari Anggaran Pendapatan Belanja Negara (APBN) dan Anggaran Pendapatan Belanja Daerah (APBD).

\section{Kesimpulan}

Berdasarkan hasil penelitian dan pembahasan pada skripsi yang berjudul “Peran Partai Golkar Dalam Melaksanakan Pendidikan Politik Bagi Masyarakat Kabupaten Bone Menurut Undang-Undang Nomor 2 Tahun 2011 Tentang Partai Politik (Studi Dewan Pimpinan Daerah Partai Golkar Kabupaten Bone)" dapat diambil beberapa kesimpulan sebagai berikut:

Partai Golkar sebagai salah satu partai politik yang berada di Kabupaten Bone telah menjalankan salah satu fungsi partai politik yaitu melaksanakan pendidikan politik kepada kader, simpatisan, maupun masyarakat secara umum. Penjabaran pendidikan politik yang dilakukan oleh Partai Golkar melalui Sosialisasi, dialog, visitasi (kunjungan), spanduk, pamplet, diskusi, seminar, media massa, dan kontak politik langsung.

Hambatan yang dihadapi oleh Partai Golkar dalam melaksanakan pendidikan politik di Kabupaten Bone masih rendannya tingkat keikutsertaan masyarakat Kabupaten Bone dalam pertemuan-pertemuan yang diselenggarakan oleh Dewan Pengurus partai Golkar Kabupaten Bone. Masih adanya sikap pragmatis dan paternalistik dari masyarakat yang pasif pada setiap pertemuan-pertemuan yang dilakukan oleh Dewan Pengurus Daerah Partai Golkar kabupaten Bone dan terkadang Anggaran Pendapatan Belanja Negara (APBN) dan Anggaran Pendapatan Belanja Daerah (APBD) terlambat diberikan kepada Dewan Pengurus Daerah Partai Golkar

${ }^{101}$ H. Andi Zainuddin, SH., Kader DPD Partai Golkar, wawancara oleh penulis tanggal 23 Januari 2018. 
Kabupaten Bone, hal ini tentu menjadi permasalahan apabila Anggaran Pendapatan Belanja Negara (APBN) dan Anggaran Pendapatan Belanja Daerah (APBD) terlambat diberikan otomatis Dewan Pengurus Daerah Partai Golkar Kabupaten Bone tidak dapat melaksanakan pendidikan politik baik kepada kadernya maupun kepada masyarakat kabupaten Bone.

\section{Referensi}

Arake, Lukman. Islam dan Konseptualisasi Politik Kaum Minoritas. ([t.Ed]). Cet.1; Yogyakarta: Prudent Media, 2012.

Adrian, Syahruddin Andi. Tinjauan Yuridis Pelaksanaan Pendidikan Politik Bagi Masyarakat oleh Partai Politik di Kota Makassar Berdasarkan Undangundang Nomor 2 Tahun 2011 tentang Partai Politik. Skripsi, Fakultas Hukum Universitas Hasanuddin Makassar, 2016.

Andi Zainuddin, Kader DPD Partai Golkar, wawancara oleh penulis tanggal 23 Januari 2018.

Amiruddin, Zainal Aiskin. Pengantar Metode Penelitian Hukum. ([t.Ed]). Cet.1; Jakarta: PT Raja Grapindo Persada, 2004.

Arikunto, Suharsimi. Prosedur Penelitian Suatu Pendekatan Pratek. ([t.Ed]). Cet.XII; Jakarta: PT Rineka Cipta, 2002.

Artikel Makalah Belajar Pendidikan Politik Pada Laman Website, https://artikelmakalah-belajar.blogspot.co.id/2012/01/pendidikan politik. Diakses pada hari Jumat 22 September 2017, pukul 21:13 Wita.

A.Muh.Arsyad, Kepala Seketariat DPD Partai Golkar di kantor DPD Partai Golkar Kabupaten Bone, wawancara oleh penulis tanggal 22 Januari 2018.

Bonepos. Dikutip Pada Laman Website, http://www.bonepos.com./2014/07angkagolput-di-kecematan-awangpone.html. Diakses pada hari Senin 13 November 2017 pukul 17:16 Wita.

Elvandi, Muhammad. Inilah Politikku . ([t.Ed]).t.c.; Solo: PT. Era Adicitra Intermedia, 2011.

Fadjar, Muktie Abdul. Partai Politik Dalam Perkembangan Ketatanegaraan Indonesia. Edisi Revisi. t.c. ; Malang: Setara Press, 2012.

Firman Batari, Sekretaris DPD Partai Golkar Kabupaten Bone di kantor Lembaga Hukum dan Konsultasi Hukum (Citra Keadilan), wawancara oleh penulis tanggal 18 Januari 2018. 
56 | Muhammad Ihsan

Ghony, Djunaidi M dan Alamansur Fauzan. Metodologi Penelitian Kualitatif. ([t.Ed]). Cet.3; Jogjakarta: Ar Ruzz Media, 2016.

Hasan, Muhammad tholchah dkk. Metode Penelitian Kualitatif Tinjauan Teoritis dan Praktis. ([t.Ed]). Cet.3; Surabaya: Visipress Media, 2009.

Kartono, Kartini. Pendidikan Politik Sebagai Bagian dari Pendidikan Orang Dewasa. ([t.Ed]). Cet.3; Bandung: Mandar Maju, 2009. 